\title{
IAMJ
}

INTERNATIONAL

AYURVEDIC

MEDICAL JOURNAL

\section{EFFECT OF PATHYA PALAN/ DIET, PANCHAKARMA AND AYURVEDA MEDICINE IN AAMVATA- A CASE STUDY}

\section{Neerja R. Sharma ${ }^{1}$ Preeti $^{2}$, Parvesh Kumari ${ }^{3}$}

${ }^{1}$ Prof. and H.O.D. dept. Of Swasthavritta and Yoga, Shri Dhanvantari Ayurveda College, Chandigarh,

${ }^{2}$ Assistant Professor, Dept. of Swasthavritta and Yoga, National College of Ayurveda Hisar, Haryana, India

${ }^{3}$ Assistant Professor, Dept. of Panchakarma, National Collge of Ayurveda Hisar, Haryana, India

Corresponding Author: pphalaswal21@gmail.com

\section{https://doi.org/10.46607/iamj4909082021}

(Published Online: August 2021)

Open Access

(C) International Ayurvedic Medical Journal, India 2021

Article Received: 28/07//2021 - Peer Reviewed: 06/08/2021 - Accepted for Publication: 07/08/2021

\section{Check for updates}

\begin{abstract}
The menopausal stage is the condition where a female wants to be at ease but if other ailments occur where she has to face continuous pain and agony make is more uncomfortable along with the psychological disturbances. The present case is a female patient who came with the symptoms of Aamavata (R.A.) in her menopausal age and was diagnosed with the same (Aamvata). She received Dietary guidelines along with lifestyle modification (Pathya Palan), Panchakarma therapy i.e. Vaitran Basti (medicated enema) for 7 days, Ruksha Swedana (dry sudation), Aamvatari Rasa, Trivrata Avleha, Ajmodadi churna, Giloy Satva for 1 month, later only Ajmodadi Churna and dietary guidelines for 2 months.

The application of the Ayurvedic principle shows remarkable results in this case where other treatment options are limited.
\end{abstract}

Keywords: Aamvata, R.A., Pathya Palan

\section{INTRODUCTION}

Aamvata is a disease described in classical Ayurvedic texts as a consequence of various factors or can be said as multifactorial causation of the disease, due to which unmetabolized material (Aam) is deposited in joints as 
a resultant ${ }^{1}$. As described in the classics there are 13 types of Agni which are responsible for the whole metabolism at different levels, that diminishes because of various factor that became the reason for the formation of Aam. Aamvata is correlated with Rheumatic Arthritis which is a multisystem disorder with a specific feature of inflammatory synovitis, which can damage cartilage and bones in chronic condition ${ }^{2}$. Further discussed patient is a known case of RA shown classical symptoms of Aamvata/R.A., which shows R.A. positive, CRP positive, ESR raised significantly. The patient is a middle-aged female, psychologically disturbed because of the continuous stage of pain and agony and didn't get precise benefits because of previous treatment she was taking, which brings her here to get maximum benefit in overall health.

She was diagnosed as a case of Aamavata and treated according to Ayurveda Principles i.e. Pathya Palan, Shodhan and Shaman i.e. dedicated dietary and lifestyle guidelines, Vaitran Basti (for 7days), Ruksha Swedan and Medication ${ }^{3}$. A considerable improvement had been noticed in joints pain, morning stiffness within 10 days, patient didn't find a need for analgesics which were needed previously. Quantitative R.A. factor, ESR, decreased gradually

\section{CASE REPORT}

A 55-year-old female patient came with C/O Pain and swelling in all joints (more intense in knee, elbow and metacarpophalangeal joints) with morning stiffness which lasts up to 1-2 hours, loss of appetite and indigestion from 2 years, according to the patient symptoms persists whole day but intense in the morning.

On examination- it shows tenderness and restricted mobility in joints. On investigation, it was $\mathrm{Hb} 10.5 \mathrm{gm}$, ESR - 40mm $1^{\text {st }}$ hour, R.A. positive $350.65 \mathrm{IU} / \mathrm{mL}$, CRP- positive.

Diagnosis - It was a case of Aamvata according to Ayurveda with differential diagnosis of Sandhigatavata (osteoarthritis) and Vatarakta (Gout), as per the examination, there is the involvement of small and big joints but no specific symptoms of vitiation of Rakta which brings a conclusion to rule out of Vatarakta. The absence of the symptom i.e. Vatapurna Druti Sparsha helps in rule out Sandhigatavata ${ }^{4}$
Hence owing to the symptoms of bodyache (Angamarda), anorexia (Aruchi) stiffness (Stambha) and severe tenderness in joints bring it out as a case of Aamvata $^{5}$. It was a case of R.A. according to the criteria given by the American College of Rheumatology (and European league against rheumatism (EULAR) $2010^{6}$.

\section{Treatment}

The patient received Dietary guidelines, along with lifestyle modification, In Shaman Aushadh Ajmodadi Churanam $3 \mathrm{gm}$ twice daily after food with Lukewarm water, Aamvatari Rasa 2 bd Giloy Satva 1/4tsf twice daily after a meal, Rasnasaptaka Kwatha $10 \mathrm{ml}$ with equal water thrice daily, Trivrut Avleha 1tsf at night with warm water. The patient had gone for Panchakarma procedure, Ruksha Baluka Swedan, along with later Vaitran Basti (including Sarvanga Abhyanga with Erand tail and Sarwanga swedan with Dashmool infused steam) formed with (guda/ jaggery 24gm, Amlika 50gm, Til tail 50ml, Saindhav 12gm, Gomutra 200ml), Vaitran Basti is given for 7 days. Later the patient was discharged with an indication of Pathya and Medicines Due to Covid patient was unable to come to the hospital for 3 months but was in touch telephonically and regularly following given guidelines. Guidelines are given to the patient (Pathya)- Daily body massage with Tripahala powder (Udvartana) 5-10 minutes, eat food only when felt hunger, intake only lukewarm water, hot fomentation, or dry sudation for 5-10 minutes. In breakfast - intake of aged grains like mung beans/ Moth beans(steamed or boiled), sprinkled with rock salt and Panchkol powder, fruits can be taken according to the availability Pomegranate, Amalaki, Cheeku, Papaya etc, in Lunch have to take Chapati (Yava, Godhum) 1-2 according to digestive fire, rice cooked with the infusion of Lavanga and Jeerak $1 / 2$ to small 1 bowl, Daal, Vegetable suitable - Karela, Parmal, Baingan, Sehjan Phali, Bathua, Palak, 1 glass of Takra with roasted Jeerak/ Yavani powder. Evening - Dashmool decoction (herbal tea) mixed with jaggery, sporadically cooked Shayamak/ roasted Chana, Dinner must be between 6.30-7.30 (preferable before sunset) - aged grains/ rice to be avoided at night, vegetable cooked with Rason, 
milk boiled wit Pipalli churanam. At night 30 minutes before sleeping usually around $9-9.30 \mathrm{pm} 10 \mathrm{ml}$ Erand Tail with warm water.

However, this patient was well adapted to the dietary regimen but in another case-patient complain about Pitta Vriddihi because of Erand tail intake at night that was resolved by intake of Amalaki Churanam or other Pittashaman or Rechan food articles.

\section{Treatment outcome}

At the end of the first 10 days of oral medication and Ruksha Baluka Swedan there was a slight reduction in pain and swelling and the patient stopped the intake of analgesics from day $3^{\text {rd }}$, which she was taking for a long. After that Vaitran Basti was planned and given for consecutive 7days, morning stiffness was reduced to 15-20 minutes which was initially at around 1-2 hours, anorexia is reduced, body ache stiffness and pain was reduced. After completion of a total of 17 days of panchakarma and oral medicine, the patient shows remarkable improvement.in continuation of Pathya i.e. dietary regulation and modification along with oral medicine for 127 days the patient (16/03/2021 -20/07/2021), there was a marked improvement in the symptoms, ESR within limits, CRP - negative, R.A. Factor below 20 IU, morning stiffness is sporadically present for few minutes, body aches joint pain is not present for now, there is no aggravation of the diseases till July 2021.

\section{DISCUSSION}

The worldwide prevalence of RA is estimated between $0.3 \%$ and $1 \%$ and is commonly seen in women in developed countries ${ }^{7}$. In India, the prevalence is estimated to be $0.75 \%$. However, there is no specific cause that can be clearly understood, disability because the condition can lead towards mental agony and later psychological condition. However, in Ayurveda, there is no marked demarcation that the prevalence rate is high in women or men. In the present case, the female is suffering from the condition diagnosed as Aamvata with clear symptoms as defined in classics. In Ayurveda, we consider Aamvata as Rasavaha Strotasa Dusti Vyadhi which means the major effect of dietary habits, its metabolism and lifestyle which was kept as a priority in managing the condition just because Doshas were vitiated extremely so there was need of Shodhan and Shaman chikitsa also which was later shifted to Pathya palan only and patient benefitted tremendously. Ama is defined as an outcome of unmetabolized material which is later deposited in different areas and resultant in Amaja Vyadhi ${ }^{9}$. In the current case, the female was in her menopausal age which was another factor that can be considered responsible for the occurrence of the disease because of the physiological vitiation of Vata Dosha. The treatment principle given is ancient classics was adopted for the treatment as due to intake of less food and only when needed/ extreme hunger arousal helps in increasing digestive fire which help in digestion of Aam Dosha, along with that in Diet there is addition of Panchkol powder which helps as Agnideepan as well as Aampachana $^{10}$, Udvartan with Triphala coarse powder helps in passive exercise, melting Kapha and Aama along with metabolism of Aam present in extremities, enhance blood circulation to remove toxins also ${ }^{11}$, dry hot fomentation helps in metabolism of Aam and removal of toxins and brings lightness \& soothing effects $^{12}$, Nitya Virechana was given in the form of Trivrut Avleha (Sukha Virechananam) ${ }^{13}$ and later Erand Tail which helps in management of vitiated Vata as well as Rechan of extra Doshas in diet, aged food grains i.e. Godhum, Yava, Mung, Moth etc were advised because they are light to digest and don't vitiate Kapha Dosha and prevent formation of ama, Hot water intake had effect in Pachanal metabolism of Aama and increased digestive fire, other vegetables and fruits which are added had Tikta rasa predominance and had Rechak properties along with Balya properties which are helpful in this condition and which are easily available in local and no specific need of out of pocket expenditure. Viatran Basti was given as per the principle of Kshar Basti indicated by Chakradutta because it directly works in Lekhana i.e. scrapping and Rechan, Removal of Doshas ${ }^{14}$. Ajamodadi Churnam is given for Pachan of Dosha, removal of inflammatory swelling ${ }^{15}$ and removal of chances of occurrence of the condition again, Giloy satva was given to give rejuvenation and along with it due to its Tikta 
rasa it helps in the metabolization of Ama, Rasanasaptaka kwatha works on Kapha Dosha as well as Vata Dosha which was added in Shaman Ausadh. Aamavatari Ras reduces inflammation manage pain due to the condition and helps in the reduction of stiffness and swelling ${ }^{16}$. Dashmool decoction with jaggery was added to the diet as a replacement of tea to ensure its Tridosha Sahamaka effect and it had a great effect on Sotha and Shool Parashamana ${ }^{17}$.

\section{Table 1}

\section{Treatment outcome}

\begin{tabular}{|r|l|l|l|l|l|}
\hline No. & Timeline & Morning stiffness & Anorexia & Joints pain & R.A. factor(IU/ml) \\
\hline 1. & Baseline- mid-March 2021 & Severe last for 1-2 hours & Present & Severe & 350.56 \\
\hline 2. & 10 days after treatment & Slightly reduced & Absent & Slight reduced & Not done \\
\hline 3. & 17 days after treatment & $\begin{array}{l}\text { Markedly reduced last } \\
\text { for 20-30 minutes }\end{array}$ & Absent & $\begin{array}{l}\text { Markedly re- } \\
\text { duced }\end{array}$ & $>120$ \\
\hline 4. & 127 days after treatment & Absent & Absent & Absent & $>20$ \\
\hline
\end{tabular}

\section{CONCLUSION}

In the present scenario, we had negatively changed our lifestyle due to various factors for which we have to pay off in terms of ill health, and one consequence is Aamvata which is a result of different factors some of which are modifiable and preventive and with the help of Ayurveda principles even along with treatment and after that, we can provide curative services as well as preventive and avoidance of reoccurrence. This effect is seen with the treatment and Pathyapalan. More studies are needed to be done to find sustainable effects on Aamvata.

\section{REFERENCES}

1. Vaidya Sastri Laxmipati, edited by Sastri Brahamasankar, Yogaratnakara 'Vidyotini', Chaukhamba Prakashan Varanasi, aamvata Nidana verse 1-3,2017, p 564-565

2. lipskyPeter E Rheumatoid Arthritis, In LongoDL, Kapsa DL, Fauci AS, etc Harrison's Principles of Internal Medicine, $18^{\text {th }}$ edition, Vol II, Macgrew Hill,2012, p2738-52

3. Vaidya Sastri laxmipati, edited by Sastri Brahamasankar, Yogaratnakara 'Vidyotini', Chaukhamba Prakshan Varanasi, Aamavata Chikitsa verse 1,2 ,2017, p 566

4. Agnivesa, Charaka Samhita, with 'Ayurvedveddipika commentary by Chakarapanidutta' elaborated by Charaka \& Drdhabala, edited by Acharya Trikamaji Yadavaji, Chaukhamba Surbharati Prakshana, Varanasi,2019 Charak chikitsa 28, verse 37, p618
5. Vaidya Sastri laxmipati, edited by Sastri Brahamasankar, Yogaratnakara 'Vidyotini', Chaukhamba Prakshan, Varanasi, Aamvata Lakshana verse 1, ,2017, p 565

6. https://www.rheumatology.org/Portals/0/Files/2010_revised_criteria_classification_ra.pdf

7. https://europepmc.org/article/med/23327517

8. https://link.springer.com/article/10.1007/BF00301258

9. Vagabatha Acharya, Prof Tripathi Ravidutta, Astanga Hridayam (Sutra Sthanam), Chaukhamab Sanskrit Pratisthan, Delhi, 2016, Astanga HridyamaAstanaga Hridyama Sutra 13, verse25,27, p 212

10. Vaidya Sastri laxmipati, edited by Sastri Brahamasankar, Yogaratnakara 'Vidyotini', Chaukhamba Prakshan Varanasi, aamvata Nidana verse 1,2017, p 568

11. Maharishi Susrut, Shastri AmbikaDutta kaviraj, Susurut Samhita 'Ayurved-Tattava- Sandipika' Susrut chikista 24-verse 51, p 135

12. Agnivesa, Charaka Samhita, with 'Ayurvedveddipika commentary by Chakarapanidutta'elaborated by Charaka \& Drdhabala, edited by Acharya Trikamaji Yadavaji, Chaukhamba Surbharati Prakshana, Varanasi,2019, Charaka Sutra 14, verse13,9, p88

13. Agnivesa, Charaka Samhita, with 'Ayurvedveddipika commentary by Chakarapanidutta' elaborated by Charaka \& Drdhabala, edited by Acharya Trikamaji Yadavaji, Chaukhamba Surbharati Prakshana, Varanasi,2019 Charak Sutra 25, verse 40, p132

14. Sri Cakrapani Dutta, Vaidya Sastri Ravidatta commentary, Chakradatta, Chaukhamba Surbharti Prakshan, Varanasi, 2012, Niruhadhikara 73, verse34-38, p313 
15. Vaidya Sastri laxmipati, edited by Sastri Brahamasankar, Yogaratnakara 'Vidyotini', Chaukhamba Prakshan Varanasi, aamvata Nidana verse 1-3,2017, p 568

16. Dassen Govind, Prof Mishra Siddhi Nandan, Bhaisjya Ratnavali, Chaukhamba Surbharati Prakshan, Varanasi,2017, Aamavatadhikar 29/69-70, p601

17. Maharishi Susrut, Shastri AmbikaDutta kaviraj, Susurut Samhita 'Ayurved-Tattava- Sandipika' Susrut Sutra 38-verse 72, p 189

\section{Source of Support: Nil \\ Conflict of Interest: None Declared}

How to cite this URL: Preeti et al: Effect Of Pathya Palan/ Diet, Panchakarma And Ayurveda Medicine In Aamvata- A Case Study. International Ayurvedic Medical Journal \{online\} 2021 \{cited August 2021\} Available from: http://www.iamj.in/posts/images/upload/1908_1912.pdf 